\section{Tradisjon som beskytter}

Tre randomiserte studier har tidligere vist at omskjæring av unge menn gir redusert risiko for hivsmitte. Nå har man analysert data fra én av disse studiene og sett at behandlingen også reduserer forekomsten av smitte med andre seksuelt overførbare sykdommer (N Engl J Med 2009; 360: 1298-309).

Litt over 3000 ungdommer ble inkludert i denne delen av studien. Halvparten ble omskåret med én gang, den andre halvparten etter to år. I løpet av disse to årene var forekomsten av smitte både med humant papillomvirus og med herpes simplex type 2 -virus omtrent $30 \%$ lavere i behandlingsgruppen enn i kontrollgruppen. Det var ingen forskjeller når det gjaldt forekomsten av syfilis.

\section{Infeksiøs endokarditt}

I motsetning til det som er tilfellet for de fleste andre hjerte- og karsykdommer har ikke dødeligheten av infeksiøs endokarditt sunket de siste tiårene. Samtidig er sykdommen sjelden, og lærebokbeskrivelsene er ofte basert på observasjoner gjort flere tiår tilbake. Derfor har en gruppe kardiologer ved sykehus over hele verden gjennomført en prospektiv studie av 2800 pasienter med endokarditt som ble lagt inn i sykehus i perioden 2000-05 (Arch Intern Med 2009; 169: 463-73).

Nesten én av fem døde i løpet av sykehusoppholdet. Hos de aller fleste var det et akutt forløp - tre firedeler kom til sykehus etter under 30 dagers sykehistorie. Gule stafylokokker var vanligste patogene infeksjon (omkring $30 \%$ av tilfellene). Disse bakteriene var ofte ervervet i sykehus og var også forbundet med dårligere prognose.

\section{Temperament som prediktor for uføretrygd}

I en skotsk studie har man sammenholdt data fra begynnelsen av 1960-årene om hvordan lærere oppfattet sine elever med spørreskjemasvar fra elevene samlet inn over 30 år senere (Br J Psychiatry 2009; 194: 220-3). Deltakerne skulle opplyse om de var permanent arbeidsuføre.

Sannsynligheten for å være permanent arbeidsufør var økt over seks ganger hos dem som lærerne hadde betegnet som «klagere» og over tre ganger hos dem som ifølge lærerne ofte var borte fra skolen uten gyldig grunn. Disse kan ha et temperament som gjør at de senere i livet lettere enn andre føler at de ikke strekker til $i$ arbeidslivet eller fører til at de velger en unnvikende strategi når de møter problemer.

\title{
Laserbehandling av prostata
}

\section{Laserbehandling ved prostatahyper- plasi gir stabile og gode resultater, også uten spinalbedøvelse. Det viser en norsk studie.}

Fotoselektiv vaporisering av prostata (PVP) er $i$ de senere år innført $i$ urologien som et alternativ til gullstandarden transurethral reseksjon av prostata (TUR-P) for behandling av menn med vannlatingsplager pga. obstruerende prostata. Fordelen med laser sammenliknet med standardreseksjon er først og fremst mindre blødning ved inngrepet, slik at man også kan operere pasienter med f.eks. pågående behandling med warfarin eller platehemmere. Det er gjort flere studier om effekten av slik behandling, men det foreligger få langtidsdata, spesielt for uselekterte pasienter.

Ved St. Olavs hospital startet man av kapasitetshensyn i 2004 med laserbehandling istedenfor transurethral reseksjon. I halvannet år ble vel halvparten av pasientene operert med spinalanestesi eller generell anestesi, resten ble operert med periprostatisk lokalanestesi og intravenøs sedasjon. Alle pasientene ble inkludert i en studie og utredet og fulgt opp med bl.a. urodynamiske målinger (1).
De to gruppene viste seg å være helt sammenliknbare når det gjaldt variabler for avløpsforbedring, og resultatene var uendret etter to års oppfølging. Den eneste praktiske signifikante forskjellen mellom gruppene, og da i favør av lokalanestesigruppen, var postoperativ katetertid og hospitaliseringstid samt peroperativ blodtrykksreduksjon (pga. anestesien). Det var ingen uheldige hendelser som følge av blodtrykksreduksjonen, men i en pasientgruppe som kan ha suboptimal hjertefunksjon vil det være en fordel å unngå for mye blodtrykksfall.

Som følge av erfaringene som er gjort i forbindelse med studien opereres nå de fleste prostatikere ved St. Olavs hospital med laser, i lokalanestesi og sedasjon. Operasjonene foregår som dagkirurgi og er lagt til avdelingen i Orkdal.

\section{John Martin Pedersen \\ john.martin.pedersen@unn.no \\ Carl-Jørgen Arum \\ Kirurgisk avdeling \\ St. Olavs hospital \\ Litteratur \\ Pedersen JM, Romundstad PR, Mjønes JG et al. 2-year followup pressure flow studies of prostate photoselective vaporization using local anesthesia with sedation. J Urol 2009; 181: 1794-9.}

\section{Nye muligheter for lindring av kronisk smerte?}

\section{Nyere forskningsresultater øker \\ kunnskapen om behandlingsstrate- gier ved inflammatorisk og nevro- \\ patisk smerte.}

Hyperfenomener ved kronisk inflammatorisk og nevropatisk smerte er avhengig av den eksitatoriske nevrotransmitteren glutamat og dens N-metyl-D-aspartatreseptor (NMDAR).

NMDAR er en ionekanal som bl.a. består av dynamiske multiproteinkomplekser som regulerer reseptortrafikken og signalhendelser distalt for selve reseptoren. Fosforylering er en viktig mekanisme for regulering av NMDAR-funksjoner, og en av mange kinaser som bidrar til oppregulering av NMDARaktiviteter er Src-proteinkinase. Forskere i Toronto har nå fremstilt et peptid som hemmer oppregulatoren Src, dermed reduseres smertefulle hyperfenomener ved inflammatoriske smerter og nerveskadesmerter hos mus (1). Fordi selve reseptoren ikke er blokkert, observerte man ingen av de vanlige og alvorlige bivirkningene man ellers ser ved direkte blokade av NMDA-reseptoren.
- Klinisk tilgjengelige NMDAR-antagonister, som for eksempel ketamin, lindrer effektivt slik smerte, men den kliniske bruken begrenses av bivirkninger, sier professor Harald Breivik ved Universitetet i Oslo. - Dette ble vist i Audun Stubhaugs doktoravhandling allerede for ti år siden og skyldes sikkert den sentrale rolle NMDAR har i mange fysiologiske funksjoner i sentralnervesystemet, forteller han.

- Disse nye forskningsfunnene gir håp om at det kan være mulig å utvikle medikamenter som tar bort de plagsomme hyperfenomenene, f.eks. etter helvetesild, uten å forstyrre de normale og livsnødvendige fysiologiske funksjonene som NMDAR regulerer i sentralnervesystemet, sier Breivik.

\section{Åslaug Helland \\ aslaug.helland@gmail.com \\ Tidsskriftet}

\section{Litteratur}

1. Liu XJ, Gingrich JR, Vargas-Caballero M et al. Treatment of inflammatory and neuropathic pain by uncoupling SRc from NMDA receptor complex. Nat Med 2008; 14: 1325-32. 